(C) 2019 by the Arizona Board of Regents on behalf of the University of Arizona. This is an Open Access article, distributed under the terms of the Creative Commons Attribution licence (http://creativecommons. org/licenses/by/4.0/), which permits unrestricted re-use, distribution, and reproduction in any medium, provided the original work is properly cited.

\title{
THE END OF THE “GREEN OASIS": CHRONOLOGICAL BAYESIAN MODELING OF HUMAN AND ENVIRONMENTAL DYNAMICS IN THE BAHARIYA AREA (EGYPTIAN SAHARA) FROM PHARAONIC THIRD INTERMEDIATE PERIOD TO MEDIEVAL TIMES
}

\author{
Frédéric Colin ${ }^{1}$ - Anita Quiles ${ }^{2 *}$ (1) Mathieu Schuster ${ }^{3}$ - Dominique Schwartz ${ }^{4}$ • \\ Catherine Duvette $^{1} \cdot$ Sylvie Marchand ${ }^{2} \cdot$ Mennat-Allah El Dorry $^{2,5} \cdot$ Johan van Heesch $^{6}$ \\ ${ }^{1}$ Université de Strasbourg, CNRS, UMR 7044 Archimède, 5 allée du Général Rouvillois CS 5000867083 Strasbourg \\ Cedex, France \\ ${ }^{2}$ Institut Français d'Archéologie Orientale (IFAO), 37 al-Cheikh Aly Youssef Street, B.P. Qasr el-Ayni, 11652, 11441 \\ Cairo, Egypt \\ ${ }^{3}$ Université de Strasbourg, CNRS, UMR 7516 Institut Physique du Globe de Strasbourg, 1 rue Blessig, Strasbourg, \\ France \\ ${ }^{4}$ Université de Strasbourg, Faculté de Géographie et d'Aménagement, LIVE, UMR 7362, 67083 Strasbourg Cedex, \\ France \\ ${ }^{5}$ Polish Centre for Mediterranean Archaeology - Research Centre in Cairo, 14, Nazih Khalifa Street (previously Baron \\ Empain), Heliopolis, Cairo, Egypt \\ ${ }^{6}$ Bibliothèque Royale de Belgique, Cabinet des Médailles; Katholieke Universiteit Leuven, Belgium
}

\begin{abstract}
After the sharp transition to aridity that followed the "Green Sahara" episode 5500 years ago, human settlements took refuge in Egyptian oases, which have to varying extents been "Green Oases" for centuries. In that period, synchronous with the beginning of historical times, the desert's aridity is generally regarded as broadly comparable to the current period. Natural and anthropogenic deposits studied during 13 excavation campaigns in Bahariya Oasis (Egyptian Desert) suggest that a fairly clear transition from a relatively green environment to much more arid landscapes occurred in the first millennia BCE and CE. This article aims at establishing the chronology of human occupations and environmental change within this period, by combining archaeological and radiocarbon data, using Bayesian modeling. It reveals that the drying up of the environment experienced by desert farmers occurred at some point between the reigns of Antoninus Pius and Caracalla (2nd-3rd century CE). The accuracy of the produced chronological models made it possible to highlight synchronisms between the end of this "Green Oasis" phase and comparable aridification phenomena on regional and interregional scales. Similar degradation processes on remote sites inside the Roman Empire might be explained by globalized anthropogenic agencies overlapping with a broader climatic drying.
\end{abstract}

KEYWORDS: Bahariya oasis (Egypt), Bayesian modeling, climate, conventional radiocarbon dates, green oasis.

\section{INTRODUCTION}

Bahariya Oasis is a vast and deep depression in the plateau of the Western Desert of Egypt (Figure 1), about $80 \mathrm{~km}$ long and $30 \mathrm{~km}$ wide at the most. The area has attracted human settlements since prehistoric times, owing to the proximity of the water table in this topographical configuration, the presence of geological faults causing the rise of water from the Nubian sandstone aquifer (Hamdan and Sawires 2013:1337-1342; Rabeh et al. 2018) and the formation of lakes during wetter periods (Svoboda 2004, 2006, 2013; Kabaciński et al. 2015). Thanks to the accessibility of spring water and artesian wells, human communities thrived in the favorable environment of Bahariya, which served as a refuge, like other oases (Kuper 2006; Kuper and Kröpelin 2006; Briois et al. 2012), when aridity worsened after the end of the African Humid Period, some 5500 years ago (Kröpelin et al. 2008).

Since the beginning of historical times, while the aridity of the desert has generally been regarded as broadly comparable to the current period, more sites testifying to permanent

\footnotetext{
*Corresponding author. Email: aquiles@ifao.egnet.net
} 




Figure 1 Map of the sites under study in Bahariya Oasis.

occupation in Bahariya Oasis have been located. However, these vestiges received scant attention until recently because of the difficulties of access which prevailed during most of the 20th century (Colin 2013; Dospěl and Suková 2013). To fill this important gap in research on the Egyptian Sahara, the Institut français d'archéologie orientale (IFAO) and the University of Strasbourg conducted a long-term program of archaeological survey and stratigraphic excavations, from 1999 to 2014, at which point security conditions became compromised in this isolated region.

During the course of this fieldwork, settlements, fortifications, worship complexes, cemeteries, ancient mining sites, fossilized irrigation systems and networks of agricultural parcels were uncovered. The occupation of the oasis has been documented over a long period, from the end of the Old Kingdom to the modern era, based on associated artifacts and monumental typology (Colin et al. 2013:185-186). Diggings at two sites in particular, Qasr 'Allam and Qaret el-Toub (Figure 1), yielded continuous stratigraphic sequences for the first millennium BCE and the first millennium CE (Colin 2011, 2012). Thanks to natural and anthropogenic deposits archived in the same contexts on both sites, it became possible to simultaneously observe the clues left by human activities and proxies revealing the palaeoenvironment of the ancient dwellings. This long-term diachronic perspective (at least on the scale of historical time) made it clear that during the arid period that followed the "Green Sahara" episode (Larrasoaña et al. 2013), the environment also experienced milder phases (Colin et al. 2014:156; see also similar observation of a wetter period in Roman El-Deir, Kharga Oasis, Garcier and Bravard 2015:33; on a "climatic optimum" from Persian to Roman times in the district of Douch, Kharga Oasis, Bousquet 1996:49-50). 
These observations suggest that the environmental evolution of the Egyptian Sahara from Pharaonic times to the present, commonly considered as a homogeneous period of hyperaridity, deserves to be reconsidered in more nuanced fashion, at least in the distinct geographical setting of the oases. Indeed, during the first millennia BCE and CE in Bahariya, a fairly clear transition from a relatively green environment to much more arid landscapes can be observed.

In order to characterize and date this phenomenon using the methods of archaeology, archaeobotany, geophysics, sedimentology, pedology and archaeometry, an interdisciplinary team carried out a joint field campaign in Bahariya during the 2014 digging season. As the first publication of this program, this article aims to construct a chronological model of the observed environmental change. This first stage of research, based mainly on evidence recorded in excavation contexts, is essential to establish a solid foundation, which will then allow specialists to dedicate further studies to the natural and/or anthropogenic factors that led to the aridification of the oasis environment. Indeed, as the historical archaeology of Bahariya has been little studied, which means that, prior to our own work, there was no local reference corpus allowing us to date artifacts, strengthening archaeological dating tools represents a real challenge. To achieve this goal, two types of approaches can be implemented: (1) Gradually ascertaining the chronotypology of the local facies of pottery assemblages through comparison with other corpora from oases and the Nile Valley, in particular by identifying artifacts imported to Bahariya from better-known areas (Bonifay 2007; Ballet et al. 2012; Marchand 2013, 2017; Musil and Tomášek 2013). (2) A more rarely used approach (in Egypt) for field archaeology on historical periods: modeling the chronology of the sites under study by cross-examining the stratigraphic data and the archaeometric datings in a Bayesian analysis of radiocarbon dates (e.g. museological Bayesian models of Ancient Egypt chronology, Bronk Ramsey et al. 2010; Quiles et al. 2013; in field archaeology, about Prehistory, Wuttmann et al. 2012).

Taking archaeological samples out of Egypt is forbidden by law, which poses the additional challenge of having to conduct all archaeometric studies in the country. The IFAO (Cairo) has an archaeometry department where conservation, materials analysis and radiocarbon dating can be performed in Egypt. It is the only active lab where radiocarbon dating of samples collected on Egyptian archaeological sites can be carried out legally.

\section{MATERIAL AND METHODS}

\section{Periodization of Anthropic and Natural Archives in the Archaeological Stratigraphy and First Dating Approximation}

The site of Qasr 'Allam (28 20'36"N, 28 50'19"E) consists of a series of buildings belonging to a Pharaonic-era religious complex. According to hieroglyphic inscriptions impressed by seals on raw earth sealings and terracotta vases, it was originally a "Domain of Amun" (Colin 2011). At a distance of $1.3 \mathrm{~km}$, the site of Qaret el-Toub (28 $\left.21^{\prime} 13^{\prime \prime} \mathrm{N}, 28^{\circ} 50^{\prime} 52^{\prime \prime} \mathrm{E}\right)$ was first occupied by a necropolis, in use from the late $3 \mathrm{rd}$ millennium BCE to Roman times. In $288 \mathrm{CE}$, a Roman fort built over the cemetery was inaugurated in the name of emperors Diocletian and Maximian. After the army left, the construction was reoccupied continuously in Byzantine and medieval times, up to the 10th century CE, according to associated ceramics (Colin 2012).

Only two charcoal samples were taken at Qaret el-Toub for dating in Cairo, since most of the excavation process on that site was completed before the establishment of IFAO's radiocarbon 
laboratory (other samples are stored in situ for future research). The archaeological periodization on which the present article is based therefore rests essentially on the excavations of Qasr 'Allam (Colin 2013; Colin et al. 2015), which are the source of most of the archaeometric dates. The relative chronology which follows is divided into 5 periods, based on the archaeological data at our disposal.

Period I starts with the construction of a wide group of rooms surrounded by an enclosing wall (Sector 7), to which additional quarters were added gradually.

Period II begins with the construction of a large elevated building (Sector 4), over the ruins of Period I. From Period I to the end of Period II, so-called "Qasralamite" Pottery Wares (TPQ 750 , TAQ $600 \mathrm{BCE}$ ) are associated with the occupation.

After the abandonment of Period I and II buildings, Period III includes all the intercalary phases preceding Period IV. During Period III a cemetery settles in the ruins of the previous periods, which are frequented episodically.

From Period I until Period III, the natural deposits of sediments included in archaeological stratigraphy are primarily composed of fine sandy silts. Periods II and III show evidence of rainfall and alluvial deposits associated with floods, sometimes catastrophic. Various clues were observed, such as a rainwater drainage channel (in sector 7), the erosion of mud brick superstructures causing vertical drains in the walls, and mud deposits. In the outside environment, the substratum is hydromorphic in some places, where it consists of highly indurated and oxidized gley soil, which must have formed under the effect of a floating water table. This phenomenon might suggest a phase where seasonal moisture-drought sequences were more contrasted than nowadays. This phase has not been dated precisely (Late Dynastic to Roman Humid Phase), but did not predate Period I, according to the "Qasralamite" artifacts found deep in the sediment in which the soil developed.

Period IV starts when a new religious edifice is built in Sector 16 (Figure 2). After early occupation (Occupation Phase A), the nature of the sedimentary deposits changes in contrasting ways. Indeed, during Occupation Phase B, fine sediments are followed by progressively coarser elements, in a transition phase, and then the deposits consist homogeneously of coarse aeolian sands, which are evidence of intense wind activity in a dry environment. This occupation period should be understood as the time when a broader environmental change is reflected in the nature of the deposits archived in the local archaeological stratigraphy of the dwelling, both in open space (courtyard) and covered areas (roofed rooms). Dating Occupation Phase B would enable us to specify the chronology of the general drying process of the local environment.

Period V begins when the buildings in sector 16 are abandoned, perhaps as a result of sand drift becoming unendurable. The natural deposits form a thick sand dune, which has covered the site until today. During this arid phase, occasional sudden rains occurred periodically, a sequence of which was archived in the filling of ruined Room 001, before the buildings were completely covered by sand. The site continues to be visited occasionally by neighboring villagers, who sometimes set up fireplaces that we sampled for dating. In the upper part of the stratigraphy, an episode of more significant rains that occurred in short succession caused a horizon of short wet-dry cycles across the entire site (with the erosion of mudbrick walls, hydromorphic filling of buried silos, limited alluvial deposits, salt crusts), as well in Qasr 'Allam as in Qaret el-Toub (Short Humid Phase). 


\section{Location of sector 16 samples}



Figure 2 Plan of Sector 16, location of samples in their archaeological context. 
Artifacts tentatively dated 1 st-2nd century CE were found in late-period III, period IV and early-period V contexts. Accordingly, a first approximation led us to date the change towards a more arid environment in the Roman era, without being more specific. The discovery of Roman imperial coins in a construction backfill of the Sector 16 building (field season 2014), especially a coin minted in year 2 of Hadrian, then led us to narrow the probability window of the dating. At the time of the find, the archaeologist in charge of this sector ventured that the floor on the backfill had been occupied "not before $150 \mathrm{CE}$ " (descriptive sheet of locus QA 16083), partially from intuition and regardless of archaeometric dates.

This periodization, derived from the results of 13 excavation seasons on two different sites, served as a framework for the choices made in the sampling campaign and was used to constrain the statistical model of radiocarbon dating through termini ante and post quem, determined on the basis of the stratigraphy and dated artifacts (ceramics, coins).

\section{Sampling}

The samples on which this study is based were collected during two sampling phases. Some dates were obtained from samples taken during the launch phase of the radiocarbon laboratory: 1 sample in 2007, 2 in 2009, 3 in 2010, 3 in 2012, and 5 in 2013 (Tables 1, 2, and 3). A more systematic sampling campaign (14 samples) was carried out in 2014 as part of a project funded by the CNRS Interdisciplinary Mission and the French national network of Maisons des Sciences de l'Homme (ChronoClim project). The strategy of this project was to first date the end of the transition process towards aridity more precisely, by focusing on archaeological contexts linked to that particular juncture. The study of this period was made possible by a geophysical survey that led to the discovery of Roman buildings in Sector 16 (Gavazzi et al. 2017). The second phase of the fieldwork should have consisted in establishing the beginning of the wetter period by studying older archaeological layers and geological outcrops. This proved impossible because of deadly attacks in the area of the Farafra/Bahariya oases a few days after our last mission in 2014. The rarer datings of earlier contexts that we obtained in the previous years will nevertheless also be presented in this article, but, for the most part, due to these circumstances, we will focus on the wet/dry transition process in Roman times.

The samples were collected by archaeologists, inventoried in situ at the time of digging and transported to the IFAO laboratory in Cairo under the supervision of an inspector from the Egyptian Ministry of Antiquities. They consist mainly of charcoals from precisely delineated hearths (i.e. corresponding to a specific event) or scattered in a stratum (e.g. backfill under the floor of a room, providing an average date establishing the terminus post quem (TPQ) of the occupation). These fragments are at least $1 \mathrm{~cm}$ in size and can easily be extracted without being contaminated by the sediment in which they are found. Other samples consist of nearly pure ash from a thick accumulation layer at the location of a fireplace (IFAO_710) or are composed of more diffuse ash sediments (IFAO_597-598, 711-716). In the latter case, usually, ashes and micro-charcoals scattered on a floor in ancient times spontaneously mixed with the surrounding dust during the discharge and were then covered with wind deposits. As a result, analysis of organic materials extracted from this loose sediment yields an average date for diverse constituents of possibly various ages (ashes and particles included in silty sand). Finally, 3 samples consisted of plant fiber found in straw-tempered and litter-tempered mudbricks, taken in situ by melting the bricks in water, and then recovering the organic particles by flotation (IFAO_446, 475, 526). 
Table 1 Stratigraphic context of the samples from sector 16 (2014).

\begin{tabular}{|c|c|c|}
\hline Lab code & Locus & Stratigraphic context \\
\hline FAO_0693 & A 16004 & Heartin on the sand (the sile is completery bur \\
\hline IFAO_0694 & A 16016 & $\begin{array}{l}\text { Hearth on the silting of Room } 01 \text {, under the final layer of } \\
\text { destruction. }\end{array}$ \\
\hline AO_0695 & A 16038 & Hearth on the first floor of Room 01 . \\
\hline IFAO_0696 & QA 16062 & $\begin{array}{l}\text { Charcoals included in the sand silting of ruin, produced in the } \\
\text { last phase of occupation of Room } 04 \text {. }\end{array}$ \\
\hline IFAO_0697 & QA 16076 & $\begin{array}{l}\text { Charcoals included in the sandy soil of the occupation phase } \\
\text { of Room } 06 .\end{array}$ \\
\hline IFAO_0698 & QA 16077 & $\begin{array}{l}\text { Charcoals included in the sandy soil of the occupation phase } \\
\text { of Room } 09 \text { (level 2). }\end{array}$ \\
\hline IFAO_0699 & QA 16083 & $\begin{array}{l}\text { Charcoals included in the backfill under the floor of Room } \\
10 .\end{array}$ \\
\hline IFAO_0700 & QA 16090 & $\begin{array}{l}\text { Charcoals included in the sandy soil of the occupation phase } \\
\text { of Room } 09 \text { (level 1). }\end{array}$ \\
\hline IFAO_0701 & QA 16092 & $\begin{array}{l}\text { Charcoals included in the destruction layer of a superstructure } \\
\text { from the last phase of occupation of Room } 10 \text {. }\end{array}$ \\
\hline IFAO_0702 & QA 16096 & $\begin{array}{l}\text { Charcoals included in the sandy soil of the occupation phase } \\
\text { of Room } 09 \text { (level 1). }\end{array}$ \\
\hline IFAO_0703 & QA 16097 & $\begin{array}{l}\text { Charcoals included in the backfill under the floor of Room } 06 \\
\text { (with possible contamination from higher layers). }\end{array}$ \\
\hline IFAO_0704 & QA 16113 & $\begin{array}{l}\text { Charcoals included in the sandy soil of the occupation phase } \\
\text { of Room } 05 .\end{array}$ \\
\hline IFAO_0705 & QA 16140 & $\begin{array}{l}\text { Charcoals included in the destruction layers of a mudbrick- } \\
\text { build hearth operated during phase } 1 \text { of Room } 10 .\end{array}$ \\
\hline IFAO_0706 & QA 16141 & $\begin{array}{l}\text { Charcoals included in the destruction layers of a mudbrick- } \\
\text { build hearth operated during phase } 1 \text { of Room } 10 \text {. }\end{array}$ \\
\hline IFAO_0707 & QA 16147 & $\begin{array}{l}\text { Charcoals included in the sandy soil of the occupation phase } \\
\text { of Room } 07 \text { and related to hearth QA } 16158 \text {. }\end{array}$ \\
\hline IFAO_0708 & QA 16162 & Charcoals included in the natural soil of the outer space 02 . \\
\hline IFAO_0709 & QA 16176 & $\begin{array}{l}\text { Ashes and charcoals mixed with sand, prior to the } \\
\text { construction of staircase QA 16171, in the outer space } 02 \text {. }\end{array}$ \\
\hline
\end{tabular}

\section{Radiocarbon Dating}

Radiocarbon dating analyses were performed at the IFAO radiocarbon laboratory, using the conventional liquid scintillation counting method (Quiles et al. 2017). Sediments and charcoal samples were first examined under a microscope and then physically cleaned to avoid any contamination with external carbon. Charcoal samples were cleaned using AAA pretreatment $(\mathrm{HCl}, 8 \%(80 \mathrm{o} . \mathrm{C})$; $\mathrm{NaOH}, 0.1-0.5 \mathrm{~N} ; \mathrm{HCl} 8 \%$ ), and sediment using $\mathrm{HCl}(8 \%)$ cleaning. They were then neutralized using a hand-made automated ultra-pure water system containing a set of filters (sand, bacteria, UV, resin). After being dried in an oven at $\sim 70^{\circ} \mathrm{C}$, samples were converted into carbon dioxide $\left(\mathrm{CO}_{2}\right)$, using a combustion bomb with a tungsten filament and under a steam of 10 bars oxygen for charcoal samples, and using a tubular furnace heated at $750-800^{\circ} \mathrm{C}$ under an oxygen stream of 1 bar for sediments. Once purified, an aliquot of $\mathrm{CO}_{2}$ gas was taken for $\delta^{13} \mathrm{C}$ determination by isotope-ratio mass 
Table 2 Results of radiocarbon determinations on charcoal samples, performed at the IFAO lab in 2016 [upper section], results previously obtained (2010-2013) on samples from Bahariya sites (* estimated value) [lower section].

\begin{tabular}{|c|c|c|c|c|c|c|}
\hline Lab code & Sampling date and fieldcode & Locus & Material & $\delta^{13} \mathrm{C}(\%)$ & ${ }^{14} \mathrm{C}(\mathrm{BP})$ & $1 \sigma$ \\
\hline$\overline{\text { IFAO_0693 }}$ & 2013 , no. 26 & QA 16004 & Burnt date stones & -25.2 & 117 & 64 \\
\hline IFAO_0694 & 2013 , no. 27 & QA 16016 & Charcoal & -26.1 & 1763 & 30 \\
\hline IFAO_0695 & 2013 , no. 28 & QA 16038 & Charcoal & -27.7 & 1889 & 32 \\
\hline IFAO_0696 & 2014 , no. 29 & QA 16062 & Charcoal & -27.2 & 1829 & 32 \\
\hline IFAO_0697 & 2014 , no. 30 & QA 16076 & Charcoal & -26.6 & 1781 & 32 \\
\hline IFAO_0698 & 2014 , no. 31 & QA 16077 & Charcoal & -27.5 & 1853 & 32 \\
\hline IFAO_0699 & 2014 , no. 32 & QA 16083 & Charcoal & -27.0 & 1812 & \\
\hline IFAO_0700 & 2014, no. 33 & QA 16090 & Charcoal & -25.0 & 2069 & 32 \\
\hline IFAO_0701 & 2014 , no. 34 & QA 16092 & Charcoal & -29.0 & 1831 & 32 \\
\hline IFAO_0702 & 2014, no. 35 & QA 16096 & Charcoal & -27.6 & 1830 & 3 \\
\hline IFAO_0703 & 2014 , no. 36 & QA 16097 & Charcoal & -27.2 & 1783 & 3 \\
\hline IFAO_0704 & 2014, no. 37 & QA 16113 & Charcoal & -27.6 & 1821 & 3 \\
\hline IFAO_0705 & 2014, no. 38 & QA 16140 & Charcoal & -27.7 & 1827 & 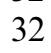 \\
\hline IFAO_0706 & 2014 , no. 39 & QA 16141 & Charcoal & -27.9 & 1884 & 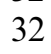 \\
\hline IFAO_0707 & 2014 , no. 40 & QA 16147 & Charcoal & -25.2 & 1877 & \\
\hline IFAO_0708 & 2014 , no. 41 & QA 16162 & Charcoal & -27.8 & 1801 & 3 \\
\hline IFAO_0709 & 2014 , no. 42 & QA 16176 & Charcoal & -27.1 & 1860 & 3 \\
\hline \multicolumn{7}{|c|}{ Previous analyses (2010-2013) } \\
\hline IFAO_0446 & 2010, no. 17 & QA Sect. 4 platform & Straw & -21.1 & 2568 & 42 \\
\hline IFAO_0461 & 2009, no. 12 & QA C413.006 & Date stone & -23.1 & 1585 & 45 \\
\hline IFAO_0465 & 2007 1FQA07 & QA 13025 & Charcoal & -23.0 & 2172 & 45 \\
\hline IFAO_0475 & 2009, no. 11 & QA Sect. 4 platform & Litter & $-25.0 *$ & 2410 & 53 \\
\hline IFAO_0526 & 2010, no. 19 & QA Sect. 7 surrounding wall & Straw & $-25.0^{*}$ & 2654 & 3 \\
\hline IFAO_0595 & 2012 , no. 22 & QA 5102 & Date stone & -29.1 & 718 & \\
\hline IFAO_0596 & 2012 , no. 22 & QA 5102 & Date stone & -29.3 & 717 & 3 \\
\hline IFAO_0597 & 2012 , no. 23 & QA 15009 & Sediment & -26.8 & 579 & 3 \\
\hline IFAO_0598 & 2010 , no. 20 & QA 7818 & Ashen sediment & -28.1 & 2785 & 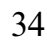 \\
\hline IFAO_0658 & 2013 , no. 24 & QT 6015 & Charcoal & -26.8 & 1121 & 30 \\
\hline IFAO_0659 & 2013 , no. 25 & QT 6015 & Burnt date stones & -24.7 & 1136 & 30 \\
\hline
\end{tabular}


spectrometry (IRMS) on a Thermo Delta V Plus at the Stratochem laboratory in Cairo. The rest was slowly released into a furnace in the presence of molten lithium in stoichiometric quantity with an excess of $1 \mathrm{~g}$ to form lithium carbide $\left(\mathrm{Li}_{2} \mathrm{C}_{2}\right)$. Once the lithium carbide was cooled, it was slowly hydrolyzed into acetylene gas $\left(\mathrm{C}_{2} \mathrm{H}_{2}\right)$ using tritium-free water, while the evolved hydrogen was pumped away. Finally, the purified acetylene was trimerized to benzene using an alumina-vanadium-chromium catalyst, and stored in a glass vial in the fridge prior to being counted. Two liquid scintillators-bis-MSB and butyl-PBD-were dissolved in the benzene solvent in equal ratios $(0.01 \mathrm{~g})$ and the resulting cocktail was placed in two Perkins Elmer Tricarb3100 liquid scintillation counters. Samples were measured around 8 times alternatively on the 2 counters.

The ${ }^{14} \mathrm{C}$ activity was calculated in percent relative to the activity of an international standard of oxalic acid (OxII), using the Libby half-life (5568 yr) and taking into account the isotopic fractionation normalized to -25\% VPDB (Stuiver and Polach 1977; Mook and van der Plicht 1999).

\section{Archaeobotanical Studies}

An archaeobotanical study was conducted at the IFAO material study lab. Some of the samples were dry-sieved using 3 sizes of geological sieves $(2 \mathrm{~mm}, 0.5 \mathrm{~mm}$, and $0.25 \mathrm{~mm})$. Observations were performed using a Leica microscope.

\section{Isotopic and TOC Analyses}

${ }^{13} \mathrm{C}$ isotopic analyses were carried out on sediments, charcoal and seeds raw material. Acid washings $(\mathrm{HCl}, 8 \%)$ were performed at the IFAO material study lab; samples were then measured using Isotope-Ratio Mass spectrometry (IRMS) on a Thermo Delta V Advantage at the Stratochem Laboratory in Cairo. After bulk combustion, products were split and sent to the isotope ratio mass spectrometer to be ionized, separated and detected.

Total organic carbon (TOC) analyses were performed on the LECO 230 instrument at the Stratochem Lab in Cairo after being decarbonized at the IFAO lab. Combustions were carried out using an induction furnace and carbon was measured by infrared absorption.

\section{RESULTS}

\section{Archaeobotanical Studies}

Statistical determinations were possible only for some of the samples, when these were transported to Cairo in 2014 in sufficient quantities (other samplings planned for the subsequent years were cancelled due to unsuitable security conditions). Grape pips dominated in the samples, which also included many olive stones. Cereals were rare and there were no weeds and (almost no) legumes. The remains were all charred.

\section{Radiocarbon Dating}

\section{Charcoal Samples}

Seventeen radiocarbon determinations were performed on charcoal specimens excavated in different stratigraphic layers (Table 1). $\delta^{13} \mathrm{C}$ values are consistent between -29.0 and $-25.2 \%$, and except IFAO_0693, which gave a modern age, all samples provided results spanning 
Table 3 Results on sediment samples analyzed between 2015 and 2017.

\begin{tabular}{|c|c|c|c|c|c|c|c|c|c|c|c|}
\hline $\begin{array}{l}\text { RestMat } \\
\text { lab code }\end{array}$ & $\begin{array}{l}{ }^{14} \mathrm{C} \text { lab } \\
\text { code }\end{array}$ & Lab code & Site code & Locus & Materials & $\begin{array}{c}\text { Botanical } \\
\text { identification }\end{array}$ & $\begin{array}{c}\delta^{13} \mathrm{C}(\%) \\
\left(\mathrm{CO}_{2}\right)\end{array}$ & $\begin{array}{l}{ }^{14} \mathrm{C} \\
(\mathrm{BP})\end{array}$ & $1 \sigma$ & TOC & $\begin{array}{c}\delta^{13} \mathrm{C}(\%) \\
\text { (rock) }\end{array}$ \\
\hline 6368 & & IFEG000073 & 2014, no. 3 & QA 16181 & Sediment & & & & & 0.99 & $\begin{array}{l}-14.9 \\
-15.1 \text { (rep }\end{array}$ \\
\hline 9949 & & & & & Seeds & $\begin{array}{l}\text { Vitis vinifera } \mathrm{L} \\
\text { (grape, pips) }\end{array}$ & & & & & -25.5 \\
\hline 6369 & & & 2014, no.49 & QA 16127 & Sediment & & & & & & \\
\hline 9950 & & & & & charcoal & & & & & & -21.1 \\
\hline 9951 & & & & & Seeds & $\begin{array}{l}\text { Olea europaea } \\
\text { L. (olive, } \\
\text { stones) }\end{array}$ & & & & & -21.1 \\
\hline & IFAO_0710 & & 2014, no. 43 & QA 16181 & Sediment & & -24.5 & 1872 & 32 & & \\
\hline 9952 & & IFEG000074 & & & & & & & & 1.59 & $\begin{array}{l}-23.5 \\
-23.7 \text { (rep }\end{array}$ \\
\hline 9953 & & & & & Seeds & V. vinifera & & & & & \\
\hline 9954 & & & & & Seeds & & & & & & -25.1 \\
\hline 9955 & IFAO_0711 & & 2014, no.44 & QA 16158 & Sediment & & -24.2 & 2028 & 30 & & \\
\hline 9956 & & & & & Charcoal & & & & & & -20.2 \\
\hline 9957 & & & & & Seeds & V. vinifera & & & & & -25.1 \\
\hline 9958 & & & & & Seeds & V. vinifera & & & & & -25.7 \\
\hline 9959 & IFAO_0712 & & 2014, no.45 & QA 16146 & Sediment & V. vinifera & -22.1 & 3584 & 32 & & \\
\hline 9960 & IFAO_0713 & & 2014, no. 46 & QA 16100 & Sediment & V. vinifera & -24.6 & 2799 & 30 & & \\
\hline 9961 & & & & & Seeds & & & & & & -24.8 \\
\hline 9962 & IFAO_0714 & IFEG000075 & 2014, no. 47 & QA 16163 & Sediment & V. vinifera & -22.7 & 2502 & 30 & 0.20 & $\begin{array}{l}-18.7 \\
-18.7 \text { (rep }\end{array}$ \\
\hline 9963 & & & & & Seeds & $V$. vinifera & & & & & -26.7 \\
\hline 9964 & IFAO_0715 & IFEG000076 & 2014, no. 48 & QA 16151 & Sediment & $\begin{array}{c}\text { Phoenix } \\
\text { dactylifera } \mathrm{L} . \\
\text { (date, stones) }\end{array}$ & -23.7 & 2495 & 32 & 0.13 & -20.0 \\
\hline 9965 & & & & & Charcoal & & & & & & $\begin{array}{l}-19.8(\text { rep } \\
-25.5\end{array}$ \\
\hline 9966 & IFAO_0716 & IFEG000077 & 2014, no.49 & QA 16127 & Sediment & & -22.9 & 3211 & 31 & 0.33 & $\begin{array}{l}-22.9 \\
-22.6(r e p\end{array}$ \\
\hline 9967 & & & & & Charcoal & & & & & & -25.5 \\
\hline 9968 & & & & & Seeds & O. europaea & & & & & -22.0 \\
\hline
\end{tabular}


from $2069 \pm 32$ to $1763 \pm 30 \mathrm{BP}$ (Table 2, Figure 3). The calibrated ranges are between $176 \mathrm{cal}$ BCE- 2 cal CE and 144-381 cal CE (95.4\%).

\section{Sediment Samples}

Seven radiocarbon determinations were performed on sediment samples (Table 3, Figure 3). $\delta^{13} \mathrm{C}$ values are between -24.6 and $-22.1 \%$ and radiocarbon age between $3584 \pm 32 \mathrm{BP}$ and $1872 \pm 32$. Hence, calibrated densities range from 2031-1785 cal BCE to 70-229 cal CE (95.4\%). Except IFAO_0710, these results are clearly older than expected since these samples were collected in the same building and at the same stratigraphic positions as the charcoal samples.

To avoid carbonate contamination, $\delta^{13} \mathrm{C}$ analyses were performed on the raw sediment, to be compared to the value obtained on $\mathrm{CO}_{2}$ gas. For 4 samples, $\delta^{13} \mathrm{C}$ values were measured on both the $\mathrm{CO}_{2}$ gas after combustion of around $1 \mathrm{~kg}$ of sediments and on an aliquot (a few $\mathrm{mg}$ ) of decarbonized sediments (Figure 4). Results are consistent. Two of them are slightly different for sample representativeness reasons: the first values on gas samples are average values from a large amount of materials, whereas the second are from only a piece of sediment. Thus, $\delta^{13} \mathrm{C}$ results (Table 3 ) clearly demonstrate that no carbonate contamination in sediments could explain the heterogeneity of ${ }^{14} \mathrm{C}$ results, as that would have yielded higher, and more scattered $\delta^{13} \mathrm{C}$ values. TOC was also tested on 5 sediment samples, ranging from 0.13 to $1.59 \% \mathrm{C}$. These scattered ${ }^{14} \mathrm{C}$ results are not due to issues during the radiocarbon analyses but relate to the origin of the analyzed sediment samples.

\section{Bayesian Modeling}

Seventeen charcoal radiocarbon determinations and the IFAO_0710 were integrated in a Bayesian model to evaluate the chronological occupation of the building in Sector 16, using OxCal 4.3 software $^{1}$ (Bronk Ramsey 1995, 2009a) and the IntCal13 calibration curve (Reimer et al. 2013). IFAO_0658, clearly an outlier, was rejected. Archaeological information was integrated as prior data. Radiocarbon dates were first incorporated into Oxcal Phases according to their stratigraphic attributions. Two archaeological occupation phases A and B were identified; phase B was divided into levels 1 and 2. The two phases were bookended by "Construction" and "End of occupation" Phases. IFAO_0703 stratigraphic attribution was not certain enough to be associated with a specific Phase, and was thus only associated with the general Sequence. Two coins dating respectively from the Year 2 of Emperor Hadrian and Emperor Domitian were found in the building's construction layers. They provide relative dates for their minting, between 29 August 117 and 28 August $118 \mathrm{CE}$ for Hadrian and between 81 and $96 \mathrm{CE}$ for Domitian. As the minting pre-dates the building's construction, the coins were included in the "Construction" Phase using After functions with uniform laws, associated with one radiocarbon date obtained on a sample found in the same archaeological layer.

In this model, the transition phase during Sector 16's occupation (Phase A/B) was simulated using the Zero_Boundary / Boundary tools to better take into account its real-time evolution. Indeed, this event rate has a ramped distribution from zero to maximum probability (transition in place), so this simulating tool seems to be consistent with such an event (Figure 6).

\footnotetext{
${ }^{1}$ For readability purposes, and to avoid confusion between archaeological and statistical notions, the OxCal tools that were used are written in italics, their names are between " ".
} 




Figure 3 Calibrated ${ }^{14} \mathrm{C}$ determinations on charcoal (black) and sediment (red) samples from Qasr 'Allam and Qaret el-Toub sites in the Bahariya Oasis (OxCal 4.3.2, IntCal13). (Please see electronic version for color figures.) 
Table 4 Results of Sector 16 building occupation modeling. Modeled ranges $(1 \sigma$ and $2 \sigma)$ for the boundaries deduced from a) model without prior information on the start and end of occupation (column 2), b) model with TPQ (absolute dates from coins) and TAQ (ceramics Dressel2/4 evidence) deduced from archaeological data (column 3).

\begin{tabular}{|c|c|c|c|c|}
\hline \multirow[b]{2}{*}{ Phases } & \multicolumn{2}{|c|}{ Model without TPQ/TAQ } & \multicolumn{2}{|c|}{ Model with TPQ and TAQ } \\
\hline & $1 \sigma(66 \%)$ & $2 \sigma(95 \%)$ & $1 \sigma(66 \%)$ & $2 \sigma(95 \%)$ \\
\hline Construction building 16 & 140-194 CE & 99-207 CE & 134-180 CE & $118-200 \mathrm{CE}$ \\
\hline Transition A/B & $164-212 \mathrm{CE}$ & $129-223 \mathrm{CE}$ & $154-203 \mathrm{CE}$ & $132-216 \mathrm{CE}$ \\
\hline End of occupation & 194-241 CE & $159-259 \mathrm{CE}$ & $174-223 \mathrm{CE}$ & $151-237 \mathrm{CE}$ \\
\hline Length of occupation & $15-73 \mathrm{yr}$ & $3-115 \mathrm{yr}$ & $10-52 \mathrm{yr}$ & $2-85 \mathrm{yr}$ \\
\hline Length of phase A & $0-28 \mathrm{yr}$ & $0-61 \mathrm{yr}$ & $0-23 \mathrm{yr}$ & $(-2)-52 \mathrm{yr}$ \\
\hline Length of phase B & $0-39 \mathrm{yr}$ & $0-86 \mathrm{yr}$ & $(-1)-28 \mathrm{yr}$ & $(-1)-61 \mathrm{yr}$ \\
\hline
\end{tabular}

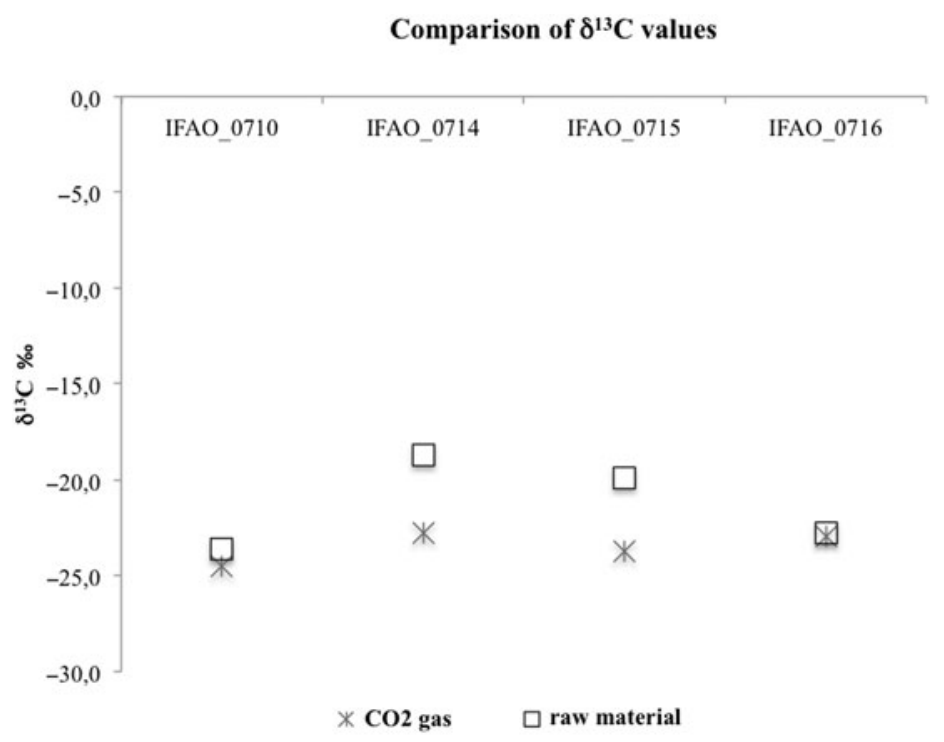

Figure 4 For sediment samples, $\delta^{13} \mathrm{C}$ values were measured on an aliquot of raw materials and on the $\mathrm{CO}_{2}$ gas obtained after combustion during the ${ }^{14} \mathrm{C}$ analysis process.

Dressel 2/4 amphoras found in the upper layers associated with the end of occupation of the building suggest the abandonment occurred before $250 \mathrm{CE}$, because this ware type becomes rarer in the Mediterranean from $150 \mathrm{CE}$ onwards and disappears totally before $250 \mathrm{CE}$. Thus, a terminus ante quem (TAQ), using the "Before" function, was added using a combine exponential law ( $\tau=-50)$ extended from $A D(150)$ to $A D(270)$ combined with an uniform law $U(A D(150), A D(270)$. It makes this constraint quite flexible, which reflects the ceramological and archaeological reality.

Outlier law distributions were described to model possible old wood effect for all the charcoal samples integrated in the model. As no information is known about this possible effect, 
a standard Outlier model("Charcoal", $\operatorname{Exp}(1,-10,0,0), U(0,3)$, " $t$ ") was applied, as recommended in Bronk Ramsey (2009a, b). Admittedly, the use of the charcoal outlier model with essentially no non-charcoal material means that the prior itself constrains the mean age of the charcoal. This bias, however, was unavoidable due to equivocal results on the sediment samples and the unavailability of other materials.

\section{INTERPRETATION AND DISCUSSION}

\section{Discrepancy between Charcoal and Sediment Dates}

Inconsistencies in the dating results of the various ash sediment samples cannot be explained by a bias in the radiocarbon analysis process. Nor are they due to the nature of the plant fragments they contain. The archaeobotanical study of samples IFAO_710 and IFAO_711-714, for example, revealed a very similar composition. They contain grape (Vitis vinifera L.) pressing remains, all charred, that may have been collected to be used as fuel or discarded as rubbish. These include pips and pip fragments, most of which had varying amounts of skin still fused onto them. One full grapefruit was recovered, indicating that the grapes are remains of grape pressing, which is in most cases evidence of wine production. In the context of such an agricultural activity, we would expect comparable dates for all these samples, with no concerns of an old wood type bias. However, only IFAO_710 provided a date consistent with the time of the occupation, all other dates being much older.

The aging of the radiocarbon dates could have been caused by the nature of the specific composition of the sediment. Indeed, the samples IFAO_597-598, 711-716 are composed of ashes that were since the time of discarding mixed with the surrounding dust and aeolian silty sand. The date obtained from this loose sediment is therefore the average age of its organic components; an apparent age raised by the presence of older carbon in the environment. A field observation reinforces this hypothesis: the author of the IFAO_712 sampling, which is the earliest date in the series, noted in situ that the sediment contained fire-rubefied silt, and ashes in small quantity. This small proportion of ashes in a matrix of older material could explain why the dating is so old. On the contrary, the fact that sample IFAO_710 was taken from the core of a thick layer of ash, better isolated from elements originating from the environment or the substrate, would explain why its radiocarbon dating is consistent with its stratigraphic position.

\section{Chronological Model for Roman Sector 16}

The model was first run without any TPQ and TAQ constraints to evaluate the start and end of the occupation at large. Without any prior information, fictive "Start" and "End of occupation" Boundaries, were integrated to model the whole occupation of the building. The model was then re-run by integrating TPQ and TAQ as defined above. The "Start" Boundary was not retained because of the After functions in the "Construction" Phase that strongly constrain the beginning of the occupation (Figure 5). Agreement model factor is quite low $(\mathrm{Am}=66)$ but acceptable as recommended by Bronk Ramsey (1995), in particular because only one date (IFAO_706) reaches a particular agreement index factor lower than $60(\mathrm{Ai}=56)$. This could be explained by the TPQ used in the Phase "construction", which is highly precise (linked with Domitian and Hadrian coins found in the excavation) and as a result very restrictive for the model. Besides, the model runs on a short time period of around 200 years. On the contrary, the TAQ linked with the ceramics data is more flexible for the upper part of the model, which provides more freedom, and 




Figure 5 Chronological modeling of the occupation of the sector 16 building at the Qasr 'Allam site, using OxCal 4.3.2 software and IntCall3 calibration curve. Charcoal determinations are in black (16), the sediment determination (1) in red, modeled boundaries in blue, and the post-abandonment ruin period has been simulated using only a boundary tool (in green). IFAO_0693 and the "End of Model" boundary were not displayed to get a closer zoom but are integrated in the modeling. 
could result in a slight imbalance in the general model. As reported in Table 4, the comprehensive model shows that the occupation of the building lasted less than 90 years $(2 \sigma)$ and most probably less than 60 . Construction did not begin before the middle of the 2nd century $\mathrm{CE}$, and the building was abandoned before the middle of the 3rd century, most probably at the beginning of the 3rd century CE.

\section{Comprehensive Chronological Model of Qasr 'Allam and Qaret el-Toub}

In addition to the chronological evaluation of Sector 16's occupation, we aimed to establish a timeline of aridification. The previous model was integrated within a wider model to get a comprehensive chronological framework of the 5 identified archaeological periods on Qasr 'Allam. Those from Periods I, II, and III are linked with the humid period (i.e. green environment) whereas Periods IV and V are associated with the dry period (demise of the green environment). Transition between humid and dry periods has been identified by archaeological studies in Period IV, between occupation phases A and B of the building in Sector 16. Eleven radiocarbon determinations previously carried out at the IFAO radiocarbon lab and coming from other sectors were incorporated in the model. They relate to archaeological Periods I to V. In 2014, the project's strategy was first to establish a firm time period for Sector 16, linked with the beginning of the dry period (upper archaeological layers) and then to date the humid periods (lower archaeological layers). Unfortunately, access to the site became impossible in 2014, and we had to build this model using only a few radiocarbon dates collected between 2007 and 2012. This explains why the older layers are based on only two ${ }^{14} \mathrm{C}$ dates linked to different sectors.

The comprehensive chronological model extends from 1100-779 BCE to the present. Qasralamite ceramic facies is associated with Period II, thus putting TPQ and TAQ in 750 and in $600 \mathrm{BCE}$ for this period. These termini were integrated using After and Before functions. Boundary functions without any prior information were used when no radiocarbon date was associated with specific periods ("Occupation Period II", "Post-abandonment ruin", "End aridity period") (Figure 6).

The model so far obtained (Table 5, Figure 6) provides temporal ranges associated with each of the archaeological periods. The Agreement model factor is of 81 and only two dates have an individual index factor lower than 60, but only slightly (IFAO_0697, Ai = 54; IFAO_0695, $\mathrm{Ai}=58)$. This model appears more balanced than the previous one because of its global structure. Start and end phases are quite flexible because they extend across longer time periods of around one millennium. The sector 16 building model is as restrictive as in Figure 5 but set at the middle of the whole model structure. In that respect it is interesting to observe that both modeled ranges are quite similar (Table 4 and Table 5), which clearly demonstrates the consistency of the model.

This final model shows that Qasr 'Allam was occupied from the Third Intermediate Period to Roman times. In Period IV, with which the building's occupation in Sector 16 is associated, the transition towards a dryer environment is set between 133 and $214 \mathrm{CE}(2 \sigma)$, which is clearly consistent with the first modeled range (132-216 CE, $2 \sigma$, Table 4). This confirms that environmental degradation occurred during the second half of the 2 nd century CE. This upgraded model also provides a more constrained range for the occupation of this building, which lasted less than 60 years. Modeled determinations for the oldest periods are not extremely accurate because of the lack of radiocarbon determinations associated with these 


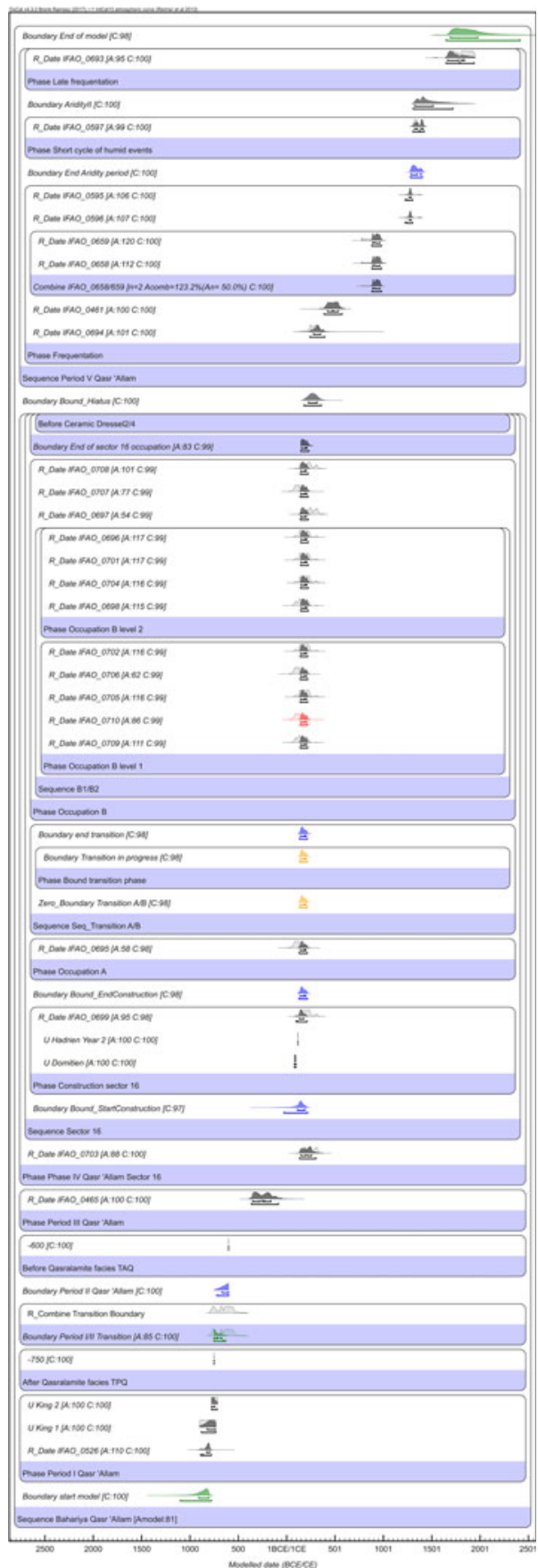

Figure 6 Comprehensive chronological model for the archaeological periods identified at the Qasr 'Allam site (Bahariya Oasis, Egypt). Eleven radiocarbon determinations previously performed at the IFAO lab on samples from Bahariya sites were integrated to cover all investigated periods (in black). The transition progress phase is in yellow. 
Table 5 Results of the Qasr 'Allam chronological model. For the 5 identified archaeological periods, time ranges are provided with a $1 \sigma$ and $2 \sigma$ range and expressed in BCE and CE. Intervals are given in number of calendar years.

\begin{tabular}{lcc}
\hline & \multicolumn{2}{c}{ Qasr 'Allam model } \\
\cline { 2 - 3 } Phases & $1 \sigma(66 \%)$ & $2 \sigma(95 \%)$ \\
\hline Start period I & $910-804 \mathrm{BCE}$ & $1100-779 \mathrm{BCE}$ \\
Transition periods I/II & $752-671 \mathrm{BCE}$ & $752-631 \mathrm{BCE}$ \\
Length "Period II + III" & $299-484 \mathrm{yr}$ & $258-577 \mathrm{yr}$ \\
End building construction (Phase IV) & $140-197 \mathrm{CE}$ & $128-213 \mathrm{CE}$ \\
Humid/dry transition in Period IV (transition in progress) & $143-202 \mathrm{CE}$ & $133-214 \mathrm{CE}$ \\
End of sector 16 occupation & $155-211 \mathrm{CE}$ & $146-230 \mathrm{CE}$ \\
Hiatus length/flash floods in a dry environment & $0-61 \mathrm{yr}$ & $0-125 \mathrm{yr}$ \\
Short cycle of humid events & $1287-1391 \mathrm{CE}$ & $1281-1403 \mathrm{CE}$ \\
Length of occupation building sector 16 & $0-23 \mathrm{yr}$ & $0-60 \mathrm{yr}$ \\
\hline
\end{tabular}

periods. In particular Periods I to III are not a posteriori modeled as continuous Phases, even though they actually were. The model would benefit from integrating more radiocarbon dates, but this could not be achieved at this stage. Additionally, the hiatus length during which flash floods occurred in the dry period lasted 125 years at the most. During this period of hyperaridity, the stratigraphy of room 001 recorded only 2 major rain events (flash floods that can erode mudbrick superstructures), clearly identifiable through silty clay deposits included in the layer of coarse sand, and about 4 less-heavy rains that have caused more diffuse deposits.

\section{Synchronisms in Environmental Change on a Wider Geographical Scale}

In theory, some of the clues of increasing aridity observed in the second half of the 2nd century $\mathrm{CE}$ could be interpreted as resulting from various types of human or natural agencies, or even from a combination of both. On the one hand, unsustainable exploitation of water for irrigation may have led to depletion of resources or degradation of soil quality (salinization), abandonment of crops and reduced protection of soils against erosion and sediment transport by wind, due to reduced vegetation cover. On the other hand, a more general deterioration of the environment may have complicated the persistence of occupation and human activities as a result of climatic drought (increased rainfall scarcity, decrease of hygrometry, heightened aeolian activity and its effects-deflation or sand drift). As announced in the introduction, the sedimentological, pedological and palaeoenvironmental issues raised by the phenomena observed will be examined in other publications. However, in the effort to identify the causes of aridification, ascertaining the chronology is of paramount importance to highlight possible synchronisms with a comparable situation in other regions and to determine if this environmental evolution has a local, regional, or interregional extension.

In the southern part of Bahariya, about $35 \mathrm{~km}$ as the crow flies from Qaret el-Toub and Qasr 'Allam, a study led by a Czech mission (Pokorný and Pokorná 2013) has shown that vegetation mounds, locally called agul, have formed by the accretion of sandy wind sediments and litter around plants with shrubby growth forms (4 species of Tamaricaceae and Acacia nilotica). As these natural formations developed in the vicinity of ancient dwellings and at the outlets of 
fossilized irrigation structures, the authors concluded that they grew on urban and agricultural terrain that would have been irrigated during the Roman period. According to this credible hypothesis, shrubs initially introduced in an irrigated environment about 1500-2000 years ago remained in relict form after the area dried up in the late Roman period (late 4th to 6th century CE), until they formed characteristic "agul" by fixing sand deposits. The general principle of the process hypothesized in this scenario is consistent with the observations of our study, which demonstrate a phenomenon of drying up after the beginning of Roman era. Yet, according to our chronology, the aridification process in northern Bahariya began some centuries earlier. It is possible that farmers effectively resisted sand drift for different durations depending on local topography (quality and sustainability of artesian waters, degree of protection provided by relief and windbreak plantations). However, the only radiocarbon date directly derived from an agul (between 379 and 660 cal CE, 93\%) was taken $4.8 \mathrm{~m}$ above its base (Pokorný and Pokorná 2013:118), which allows only to set a terminus ante quem of the beginning of its formation. It is therefore also possible that sand drift began earlier, at the same time as in the north of the oasis, and that the late Roman settlements, independently dated by archaeologists through ceramic typology, were maintained in the South for some time thanks to the exploitation of the artesian groundwater that remained available, albeit in a now less favorable environment-which would be a good example of oasis resilience.

Let us consider the question at the broader regional scale of the Western desert of Egypt oases. Recent geoarchaeological surveys in Dakhla oasis (260 km southward from Bahariya), in the ancient town of Trimithis, revealed evidence of irrigation dating from the end of the Third Intermediate Period (840-740 BCE) to the 3rd century CE (Bravard et al. 2016b). Several successive phases of sediment accretion or deflation were observed, reflecting periods when, respectively, wind-blown particles were trapped by the roughness of humid cultivated soils or, on the contrary, drying of the environment and crop decline were accompanied by significant wind erosion of soils. The chronology of one of these last episodes of crisis deserves to be compared with the facts observed at Qasr 'Allam. Indeed, a phase of severe deflation, perhaps accompanied by increased northern wind activity pushing sand dunes to the south, occurred during the 3rd century CE. The study of one yardang (Bravard et al. 2016b:313, fig. 8 ; 315, fig. 9; 318) provides a dramatic indication to the impact of the wind erosion triggered during that phase (yardangs are isolated buttes-témoins carved into thick sedimentary layers by the wind). A canal segment preserved at the top of this formation, dug in a relict of irrigation soil from the Ptolemaic period, was dated 3rd century CE, while another canal, more recent but also dated 3rd century CE, lay $3 \mathrm{~m}$ below, at the foot of the yardang, directly on the shale substrate (both dates are only deduced from the typology of associated ceramics). At the end of a period of agricultural development that had produced a gradual rise in irrigation soil, this displacement of the adduction system from top to bottom shows a powerful episode of wind erosion, active after the end of the operation of the first channel. This episode blew several meters of sediment accumulation, before the farmers, during the same century, installed a new channel directly on the substrate exposed by the erosion. This crisis period of wind-induced sediment deficit is contemporary with the drought and sand drift phase that accompanied and followed the abandonment of Sector 16 buildings at Qasr 'Allam. The main difference is that in the topography of Trimithis, the blown soils were located in an area prone to erosion, while the study site in Bahariya is located in an area where drifting sands pushed by the wind were stopped above the dwellings and on the former fields, trapped by anthropic structures and by concave reliefs concentrating the remaining moisture, then fixed by the natural, 
probably fast development of wide expanses of halfa grass (Desmostachya bipinata). At the same time, the Bahariya and Dakhla sites experienced intense wind activity, synchronous with the degradation of cultivated fields.

In Kharga oasis (over $300 \mathrm{~km}$ southeast of Bahariya), remnants of dwellings and irrigation devices were also observed on the top of some yardangs, in Douch (Crépy 2016:46; Crépy and Callot 2016:327; 331; 333) and El-Deir (Tallet et al. 2011: 184; Garcier and Bravard 2015:33), respectively at the southern and northern edges of this oasis. Depending on the site topography, the wind-sculpted layers of fine sediments accumulated during the Holocene either because the surface roughness conferred by the vegetation cover and the ambient humidity of the crops trapped the particles transported by the wind (Crépy 2016; Bravard et al. 2016:480; Bravard et al. 2016b:320), or because runoff carried colluviums down a closed depression, which formed a playa (Tallet et al. 2011; 2012). Artifacts were again used to date the human occupations that left traces at the top of the relict formations: they range from the Persian (5th century BCE) to the Roman period. At El-Deir, farmers cultivated fields on fertile playa deposits dating back to the African Humid Period. In the upper part of one yardang, consisting of a sequence of this naturally occurring sediment covered by an anthrosol formed by irrigation, a charcoal included in the filling of a channel-and therefore corresponding to a terminus ante quem of its

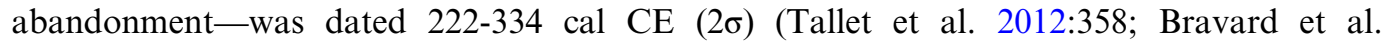
2016:472; 474; 477; UCIAM76668/ULA-1623), close to the sand drift phase of Qasr 'Allam. In the period following the operation of this canal, most of the deposit was again blown by the wind. In this case, severe erosion was triggered or aggravated by one or more flash floods that occurred between the 2nd and 4th century (Bravard et al. 2016:479; 482), close to the two flash floods recorded in sector 16, room 001, at Qasr 'Allam.

We might also assume that this transition sequence from a greener to a drier environment was more global in character when considering the issue on an interregional scale. In the territory of Africa Proconsularis (Eastern Algeria, Tunisia, Western Libya), an area comprising Mediterranean, semi-arid and arid climatic zones, geoarchaeology studies conducted for several decades concluded that from the 5th century BCE to the 3rd century CE, northern Africa enjoyed a climate where rainfall was more abundant (Leveau 2009). This more favorable phase was preceded and followed by drier climatic periods. We thus observe the same sequence as in Bahariya, from a relatively humid to a drier environment, with a delay in the onset of the arid phase.

Still in the arid belt, at the edges of the Roman Empire, but east of Egypt, sequences of sedimentary deposits located on the western shore of the Dead Sea made it possible to measure the fluctuations of the lake level and date them by radiocarbon (Bookman et al. 2006; McCormick et al. 2012:180; 188; 217-218). These oscillations are indicative of the general evolution of rainfall rate in its drainage basin, located between the climate zones of the eastern Mediterranean and the Levantine hyperarid desert. Studies have shown that after a long period of low lake level, a marked intensification of rainfall resulted in a lake level rise, filling the southern Dead Sea basin from about 250 BCE to around 150 CE. Then, a period of increased aridity is evidenced by the drop of the shorelines under the level of the sill separating the two basins, around 150-200 CE (Bookman et al. 2006:163, fig. 4b). 
Finally, to complete this panorama by returning to Egypt, historical records of the level and quality of the Nile flood have allowed to study its oscillation over several centuries from the Ptolemaic period (McCormick et al. 2012; Manning et al. 2017). This proxy remotely reflects the importance of monsoon rains at the Nile sources, in its middle and eastern African drainage basin. The amplitude of the flood might be an indicator of the global climate. Indeed, explosive volcanic events have been shown to be responsible for the occurrence of bad floods, since atmospheric dust and aerosol loading can cool the Northern Hemisphere for up to 10 years, which tends to reduce the precipitation-evaporation balance and to disturb the monsoon at the sources of the Nile (Sigl et al. 2015; Manning et al. 2017:3). Again, the first part of the Roman period, from $30 \mathrm{BCE}$ to $155 \mathrm{CE}$ - a period of low volcanic activity-was characterized by stability and a higher number of abundant floods favorable to Egyptian agriculture. From 155 to $299 \mathrm{CE}$, on the other hand, this proportion decreased and the bad floods were more frequent (McCormick et al. 2012:183; 188-189; 203; fig. 10).

This review suggests that the same succession of a greener and a drier phase occurred in a number of regions of the arid belt, from North Africa to the Near East, including the Egyptian oases. The chronological correlation is sometimes strong, even in the case of phenomena of more southern origin and depending on the African monsoon. Admittedly, a homogeneous economic and social model in the Hellenistic kingdoms, then in the Roman Empire, based on a rent economy where cheap labor force and water resources were abundant, may have led, in similar ways across remote areas, to unsustainable exploitation and depletion of resources, either at the same time, or, depending on the abundance of reserves, at a staggered pace. It is therefore likely that overexploitation of fossil groundwater played a role in the aridification of the oases in Roman times (as demonstrated in southern Kharga oasis e.g. by Bousquet 1996; Wuttmann et al. 2000; Crépy 2016). However, fluctuations of rainfall rates occurred simultaneously in several of these regions (North Africa, Bahariya, draining basin of the Dead Sea and Nile springs): such climate phenomena are independent of anthropogenic dynamics. This suggests that a wetter climate oscillation occurred in Egypt from the late dynastic period to the second half of the 2nd century CE. This hypothesis inspired by chronological concordances of paleoenvironmental situations should now be tested from the point of view of climate modeling. In addition, the nuances of micro-phases within the greener period should be specified and the beginning of the wetter phase, during the Third Intermediate Period, should be set as precisely as its end. The study of the Nile flood quality, for example, revealed several phases of drought in Ptolemaic era (Manning et al. 2017), which were not observed in Bahariya. This lack of evidence can be explained either because the study of older layers could not be carried to completion, or because these phases were not archived as positive stratigraphic units (an erosive process may have erased the sedimentary archiving of arid episodes), or because the climate oscillations reflected on the Nile regime did not have a major environmental impact on the oases of the Egyptian Sahara during the Ptolemaic period.

\section{CONCLUSION}

In the current context of global climate change, which generates new societal concerns and accordingly impacts historiography, the study of palaeoenvironments has been attracting growing interest, in the field of Egyptology as in other archaeological sciences. However, studies combining archaeology, archaeometry and geosciences are still rare in Egypt, although notable publications used historical records of annual Nile floods as proxies for the amplitude of monsoons in Central and Eastern Africa (McCormick et al. 2012; 
Manning et al. 2017). In this state of the art, research conducted on Egyptian Nile-independent regions is of particular significance.

Over the past decade, stimulating geoarchaeology researches conducted in the southern oases of the Egyptian Sahara, in south and north Kharga as well as in Dakhla, have emphasized the role of anthropogenic agencies in the environmental degradation process. These works, whose dating tools rely primarily on ceramology (relative ages) and secondarily on archaeometry (absolute ages), have suffered from the ban on exporting archaeological samples abroad.

Northward, the military status of the desert districts hampered archaeological research in Bahariya Oasis for decades during the 20th century. An opening window of some 15 years at the beginning of the new century allowed us to conduct 13 excavation campaigns at two archaeological sites, Qaret el-Toub and Qasr 'Allam, before the oasis was again closed to archaeological research for security reasons. To date the occupation phases highlighted through this digging work, we established a set of radiocarbon dates based on around thirty samples, and we combined them with other dating criteria so as to produce two chronological Bayesian models. One of them focuses on a religious building occupied in Roman times, which provided a large number of samples. The other extends from 1100-779 BCE to the present. The modeling counterbalanced the hundred-years-period syndrome, i.e. the tendency of archaeologists in Egypt to round up or down century-based dating estimates when they rely on the study of ceramic assemblages. In this case, the relatively short period of the building's occupation, probably less than fifty years and in any case less than a century, may have extended at the most from the reign of Hadrian to the end of the Severan dynasty. During this period, the desert farmers experienced a drying up of the environment, reflected in the area under study by rapid and widespread drift of aeolian sands on the dwellings and formerly irrigated fields, at some point between the reigns of Antoninus Pius and Caracalla. Indeed, our study has shown that the highly sandy landscape (Figure 1) surrounding the human occupations in the north of Bahariya oasis developed relatively late in Egyptian history, in the second half of the 2nd century CE. Environmental archives included in the archaeological stratigraphy suggest that the oasis previously enjoyed a much greener ecology.

The accuracy of the chronological models made it possible to highlight synchronisms between the end of this "Green Oasis" phase and comparable aridification phenomena on regional and interregional scales. Growing drought and strong wind activity occurred in Kharga, Dakhla and Bahariya in close periods. Anthropogenic factors, such as the universalization of an unsustainable economic model that overexploited fossil groundwater resources, might partially explain the occurrence of comparable degradation processes in very remote sites inside the Roman Empire. Nonetheless, the observation of synchronous rainfall decline in northern Africa, in the Dead Sea watershed, at the Nile sources and in Bahariya suggests that these anthropogenic agencies overlapped with a broader climatic drying.

After the sharp transition to aridity that followed the "Green Sahara" episode, ca. 5500 years ago, human settlements took refuge in the Egyptian oases, which have constituted, at different rates, "Green Oases" for centuries. The data from the Egyptian Sahara suggest that another desiccation transition took place from the 2nd century onwards, albeit to a lesser degree, but with very visible consequences in ancient landscapes. It seems as if, after a long period of resilience in a climatically arid environment, but one endowed with fossil groundwater resources, an aridification threshold was crossed under the not easily quantifiable effect of 
a combination of human and natural factors. After this critical threshold, agricultural development strategies became much less effective in an increasingly hostile environment. The retraction of the "Green Oasis" continued until the 20th century, when new deep-water pumping methods revived the deployment of new irrigated land, first following traditional water supply networks, then, in the 21 st century, conquering new, previously virgin territories through center-pivot irrigation techniques.

\section{ACKNOWLEDGMENTS}

This research has received funding from the interdisciplinary University of Strasbourg/CNRS Excellence Initiative program "Autour des points d'eau. Expansions et régressions d'un terroir irrigué de l'Oasis de Bahariya (Égypte), des pharaons à nos jours”, and from the CNRS Interdisciplinarity Mission in collaboration with the network of the Maisons des sciences de l'Homme, as part of the project "La chronologie d'un changement climatique : première modélisation complexe des archives géologiques et archéologiques de l'oasis de Bahariya". Additional funding was provided by the research team UMR 7044 Archimède and by the Institut français d'archéologie orientale (IFAO). We thank Jean-Philippe Droux (CNRS, UMR 7044 Archimède) for the map on Figure 1, Tarek el-Azhary and Nancy Leon from Stratochem Lab (Cairo), Essam Ahmed archaeobotanist from NMEC, Egyptian Ministry of Antiquities, and we gratefully acknowledge the Egyptian Ministry of Antiquities for its valuable support. Editorial support was provided by the Maison Interuniversitaire des Sciences de l'Homme - Alsace (MISHA) and the Excellence Initiative of the University of Strasbourg. We thank Jean-Yves Bart for his editing work on the text. We also thank the two reviewers for their constructive and thorough comments.

\section{REFERENCES}

Ballet P, Bonifay M, Marchand S. 2012. Africa vs Aegyptus : routes, rythmes et adaptations de la céramique africaine en Égypte. In: Guédon St, editor. Entre Afrique et Égypte : relations et échanges entre les espaces au sud de la Méditerranée à l'époque romaine. Scripta Antiqua, Vol. 49. Bordeaux: Ausonius Éditions. p. $87-117$.

Bonifay M. 2007. Observations préliminaires sur les amphores africaines de l'oasis de Bahariya. In: Marchand S, Marangou A, editors. Amphores d'Égypte de la Basse Époque à l'époque arabe. Cahiers de la céramique égyptienne, Vol. 8/1. Cairo: IFAO. p. 451-462.

Bookman R, Bartov Y, Enzel Y, Stein M. 2006. Quaternary lake levels in the Dead Sea Basin: Two centuries of research. In: Enzel Y, Agnon A, Stein M, editors. New frontiers in Dead Sea paleoenvironmental research. GSA Special Papers, Vol. 401. Boulder (CO): The Geological Society of America. p. 155-170.

Bousquet B. 1996. Tell-Douch et sa région. Géographie d'une limite de milieu à une frontière d'Empire. DFIFAO, Vol. 31. Cairo: IFAO.

Bravard J-P, Mostafa A, Garcier R, Tallet G, Ballet P. 2016. Rise and fall of an Egyptian oasis: artesian flow, irrigation soils, and historical agricultural development in El-Deir, Kharga depression, Western Desert of Egypt. Geoarchaeology: An International Journal 31:467-486.

Bravard JP, Mostafa A, Davoli P, Adelsberger KA, Ballet P, Garcier R, Calcagnile L, Quarta G. 2016b. Construction and deflation of irrigation soils from the Pharaonic to the Roman period at Amheida (Trimithis), Dakhla Depression, Egyptian Western Desert. Géomorphologie : relief, processus, environnement. 22(3):305-324.

Briois Fr, Midant-Reynes B, Marchand S, Tristant Y, Wuttmann M, De Dapper M, Lesur J, Newton Cl. 2012. Neolithic occupation of an artesian spring: KS043 in the Kharga Oasis, Egypt. Journal of Field Archaeology 37(3):178-191.

Bronk Ramsey C. 1995. Radiocarbon calibration and analysis of stratigraphy: The OxCal program. Radiocarbon 37(2):425-430.

Bronk Ramsey C. 2009a. Bayesian analysis of radiocarbon dates. Radiocarbon 51(1):337-60.

Bronk Ramsey C. 2009b. Dealing with outliers and offsets in radiocarbon dating. Radiocarbon 51(3):1023-45.

Bronk Ramsey C, Dee MW, Rowland JM, Higham TFG, Harris SA, Brock F, Quiles A, Wild EM, 
Marcus ES, Shortland AJ. 2010. Radiocarbonbased chronology for dynastic Egypt. Science 328:1554-1557.

Colin Fr. 2011. Le « Domaine d'Amon» à Bahariya de la XVIII à la XXVI ${ }^{\mathrm{e}}$ dynastie : l'apport des fouilles de Qasr 'Allam. In: Devauchelle D, editor. La $\mathrm{XXVI}^{\mathrm{e}}$ dynastie continuités et ruptures. Promenade saïte avec Jean Yoyotte. Actes du Colloque international; 2004 nov 26-27. Paris: Université Charles-de-Gaulle - Lille 3. p. 47-84.

Colin Fr, editor. 2012. Bahariya I. Le fort romain de Qaret el-Toub I. FIFAO, Vol. 62. Cairo: IFAO.

Colin Fr. 2013. Les gisements archéologiques de Psôbthis au début du $\mathrm{XXI}^{\mathrm{e}}$ siècle : Diagnostic sur un paysage menacé et nouvelles orientations de recherche. In: Dospěl M, Suková L, editors. Bahriya Oasis. Recent research into the past of an Egyptian oasis. Prague: Charles University. p. 151-184.

Colin Fr, Adam Fr, Duvette C, Grazi C. 2013. À la recherche des origines de Psôbthis : les premières tombes de la nécropole de Qaret el-Toub (fouilles de l'IFAO à Bahariya, état 2009). In: Dospěl M, Suková L, editors. Bahriya Oasis. Recent research into the past of an Egyptian oasis. Prague: Charles University. p. 185-226.

Colin Fr, Gavazzi Br, Munschy M, Schuster M, Schwartz D. 2014. Autour des points d'eau. Expansions et régressions d'un terroir irrigué de l'oasis de Bahariya (Égypte), des pharaons à nos jours. Idex interdisciplinaire Université de Strasbourg - Cnrs. In: Colin Fr, editor. La chronique d'Archimède. Bilan des activités scientifiques 2013-2014 de l'unité mixte de recherche 7044. Archimède. 1:156-161.

Colin Fr, Duvette C, Gavazzi Br, Munschy M, Schuster M, Schwartz D. 2015. Bahariya. Pratiques funéraires et lieux de culte. In: Midant-Reynes B, editor. Rapport d'activité 2013-2014. Supplément au BIFAO 114. Cairo: IFAO. p. 195-201.

Crépy M. 2016. Les Paysages du vent : géohistoire et géoarchéologie de la dépression de Kharga (désert Libyque, Égypte) du cinquième siècle avant notre ère à nos jours 2500 ans d'interactions entre dynamiques éoliennes et activités humaines dans un milieu hyperaride. Lyon: Doctoral thesis of Université Lumière Lyon II defended on December 2, 2016. Available at https://hal. archives-ouvertes.fr/tel-01490559.

Crépy M, Callot Y. 2016. Les dépôts de sédiments fins dans le sud de la dépression de Kharga (désert libyque, Égypte) : indices d'une morphogenèse éolienne et anthropique. Géomorphologie : relief, processus, environnement. 22/3:325-342.

Dospěl M, Suková L. 2013. Exploration of the El-Hayz Oasis: Issues, approaches, challenges. In: Dospěl M, Suková L, editors. Bahriya Oasis. Recent research into the past of an
Egyptian oasis. Prague: Charles University. p. 35-62.

Garcier R, Bravard J-P. 2015. La durabilité des oasis : aper, us de géographie historique à partir du cas de l'oasis de Kharga, Égypte. In: Marshall A, Lavie E, Chaléard J-L, Fort M, Lombard J, editors. Proceedings of the international colloquium Oases in the globalization: Ruptures and continuities. December 16-17, 2013. Paris: Villetaneuse. p. 29-35.

Gavazzi Br, Alkhatib-Alkontar R, Munschy M, Colin Fr, Duvette C. 2017. On the use of Fluxgate 3-axis magnetometers in archaeology: Application with a multi-sensor device on the site of Qasr 'Allam in the Western Desert of Egypt. Archaeological Prospection 24:59-73.

Hamdan AM, Sawires RF. 2013. Hydrogeological studies on the Nubian sandstone aquifer in El-Bahariya Oasis, Western Desert, Egypt. Arabian Journal of Geosciences 6:1333-1347.

Kabaciński J, Bobrowski P, Czekaj-Zastawny A, Jórdeczka M, Krolik H, Masojć M. 2015. Combined prehistoric expedition survey in the area of Fayum, Bahariya and Farafra Oases and Sinai. Studies in African Archaeology 14:239-271.

Kröpelin S, Verschuren D, Lézine A-M, Eggermont H, Cocquyt C, Francus P, Cazet J-P, Fagot M, Rumes B, Russell JM, Darius F, Conley DJ, Schuster M, von Suchodoletz H, Engstrom DR. 2008. Climate-driven ecosystem succession in the Sahara: The past 6000 years. Science 320:765-768.

Kuper R. 2006. After 5000 BC: The Libyan Desert in transition. Comptes Rendus Palevol 5/1-2: 409-419.

Kuper R, Kröpelin S. 2006. Climate-controlled Holocene occupation in the Sahara: Motor of Africa's evolution. Science 313:803-807.

Larrasoaña JC, Roberts AP, Rohling EJ. 2013. Dynamics of green Sahara periods and their role in hominin evolution. PLoS ONE 8/10: e76514.

Leveau Ph. 2009. Les conditions environnementales dans le nord de l'Afrique à l'époque romaine. Contribution historiographique à l'histoire du climat et des relations homme/milieu. In: Hermon E, editor. Sociétés et climats dans l'Empire romain. Pour une perspective historique et systémique de la gestion des ressources en eau dans l'Empire romain. Naples: Editoriale Scientifica. p. 309-348.

Manning JG, Ludlow F, Stine AR, Boos WR, Sigl M, Marlon JR. 2017. Volcanic suppression of Nile summer flooding triggers revolt and constrains interstate conflict in Ancient Egypt. Nature Communications 8/900:1-9.

Marchand S. 2013. La céramique de la fin de l'Ancien Empire/Première Période Intermédiaire : Tombe 10 de la nécropole de Qaret el-Toub (oasis de Bahariya). In: Dospěl M, Suková L, editors. 
Bahriya Oasis. Recent research into the past of an Egyptian oasis. Prague: Charles University. p. 227-241.

Marchand S. 2017. Remarques sur les moules à pains et les plaques de cuisson dans l'Égypte ancienne. Bulletin de Liaison de la céramique égyptienne 27:223-250.

McCormick M, Büntgen U, Cane MA, Cook ER, Harper K, Huybers P, Litt T, Manning SW, Mayewski PA, More AFM, Nicolussi K, Tegel W. 2012. Climate change during and after the Roman Empire: Reconstructing the past from scientific and historical evidence. Journal of Interdisciplinary History. 43/2:169-220.

Mook WG, van der Plicht J. 1999. Reporting ${ }^{14} \mathrm{C}$ activities and concentrations. Radiocarbon 41(3):227-239.

Musil H, Tomášek M. 2013. Die Besiedlung in der Oase el-Hays in der Römerzeit: Auswertung der Funde. In: Dospěl M, Suková L, editors. Bahriya Oasis. Recent research into the past of an Egyptian oasis. Prague: Charles University. p. 63-77.

Pokorný P, Pokorná A. 2013. "Agoul landscapes” in the oases of the Western Desert of Egypt: Ecology and palaeoecology of vegetation mounds in El-Hayz, Southern Bahriya. In: Dospěl M, Suková L, editors. Bahriya Oasis. Recent research into the past of an Egyptian oasis. Prague: Charles University. p. 113-121.

Quiles A, Aubourg E, Berthier B, Delque-Kolic E, Pierrat-Bonnefois G, Dee MW, Andreu-Lanoë D, Bronk Ramsey C, Moreau C. 2013. Bayesian modelling of an absolute chronology for Egypt's 18th Dynasty by astrophysical and radiocarbon methods. Journal of Archaeological Science 40:423-432.

Quiles A, Sabri Kamal N, Abd'el Fatah M, Mounir N. 2017. The Ifao Radiocarbon laboratory: A status report. Radiocarbon 59(4):1157-1169.

Rabeh T, Bedair S, Abdel Zaher M. 2018. Structural control of hydrogeological aquifers in the Bahariya Oasis, Western Desert, Egypt. Geosciences Journal 22/1:145-154.

Reimer PJ, Bard E, Bayliss A, Beck JW, Blackwell PG, Bronk Ramsey C, Buck C, Cheng H, Edwards RL, Friedrich M, Grootes PM, Guilderson TP, Haflidason H, Hajdas I, Hatté C, Heaton TJ, Hoffmann DL, Hogg AG, Hughen KA, Kaiser KF, Kromer B, Manning SW, Niu M, Reimer RW, Richards DA, Scott
EM, Southon JR, Staff RA, Turney CSM, van der Plicht J. 2013. IntCal13 and Marine13 radiocarbon age calibration curves $0-50,000$ years cal BP. Radiocarbon 55(4):1869-1887. doi:10.2458/azu_js_rc.55.16947.

Sigl M, Winstrup M, McConnell JR, Welten KC, Plunkett G, Ludlow F, Büntgen U, Caffee M, Chellman N, Dahl-Jensen D, Fischer H, Kipfstuhl S, Kostick C, Maselli OJ, Mekhaldi F, Mulvaney R, Muscheler R, Pasteris DR, Pilcher JR, Salzer M, Schüpbach S, Steffensen JP, Vinther BM, Woodruff TE. 2015. Timing and climate forcing of volcanic eruptions for the past 2,500 years. Nature 523:543-549.

Stuiver M, Polach HA. 1977. Reporting of ${ }^{14} \mathrm{C}$ data. Radiocarbon 19(3):355-363.

Svoboda JA. 2004. The Middle Paleolithic of Southern Bahariya Oasis, Western Desert, Egypt. Anthropologie 42/3:253-239.

Svoboda JA. 2006. Prehistory of the Southern Bahariya Oasis, Western Desert, Egypt. An outline. Archaeology, Ethnology and Anthropology of Eurasia 28:18-30.

Svoboda JA. 2013. Prehistory of the Southern Bahariya: A case study in Northeast African Settlement Archaeology. In: Dospěl M, Suková L, editors. Bahriya Oasis. Recent research into the past of an Egyptian oasis. Prague: Charles University. p. 35-62.

Tallet G, Garcier R, Bravard J-P. 2011. L'eau disparue d'une micro-oasis : premiers résultats de la prospection archéologique et géoarchéologique du système d'irrigation d'El-Deir, oasis de Kharga, Égypte. In: Abadie-Reynal C, Provost S, Vipard P, editors. Les Réseaux d'eau courante dans l'Antiquité, Rennes: Presses Universitaires de Rennes. p. 173-188.

Tallet G, Bravard J-P, Guédon St, Mostafa A. 2012. The survey project at El-Deir, Kharga Oasis: First results, new hypotheses. In: Bagnall RS, Davoli P, Hope CA, editors. New perspectives on the Western Desert of Egypt. Oasis Papers, Vol. 6. Oxford: Oxbow Books. p. 349-361.

Wuttmann M, Gonon Th, Thiers C. 2000. The Qanats of 'Ayn-Manâwîr (Kharga Oasis, Egypt). Journal of Achaemenid Studies and Researches 1/1: 1-8.

Wuttmann M, Briois Fr, Midant-Reynes B, Dachy T. 2012. Dating the end of the Neolithic in an Eastern Sahara oasis: Modeling absolute chronology. Radiocarbon 54(3-4):305-318. 